\title{
Perspectives
}

\section{Framing the Problem of Identity in Composition and TESOL Studies: A Sampler}

\section{Hayat Messekher}

This article looks at how the intricate issue of identity has been addressed and framed in composition and TESOL studies (CET). It reviews five articles and a book as a sampler to explore identity research in various contexts ranging from the problematic rise of identity in second-language acquisition (SLA) research in 1997, which represented a paradigm shift in SLA research, to other research dealing with second-language (L2) learners' identity, identity in a teacher training program (i.e., identity of student teachers), and finally, teacher identity as a transformative pedagogy.

Cet article étudie la façon dont a été abordée et présentée la question complexe de l'identité dans les études en composition et en enseignement de l'anglais aux locuteurs d'autres langues (Composition and TESOL Studies). Nous nous penchons sur cing articles et un livre pour examiner la recherche sur l'identité dans divers contextes, de la montée problématique de la question de l'identité dans la recherche sur l'acquisition d'une langue seconde en 1997(ce qui a représenté un changement de paradigme dans la recherche en ALS) à l'identité des enseignants comme pédagogie transformative en passant par d'autre recherche sur l'identité des apprenants de langue seconde et l'identité dans le contexte d'un programme de formation des enseignants.

\section{Introduction}

Scholars characteristically seek to make advancements in their respective fields and to add to the body of existing knowledge. One way to do this is by addressing problems that have not yet been investigated or by discovering ramifications of problems that have already been addressed by reframing them. Scholars frequently proceed consistently by highlighting and addressing a gap in the literature that has theoretical or epistemological implications. This may sometimes give rise to scientific revolutions and bring about paradigm shifts (Kuhn, 1962). Hence I analyze how problems are posed around one of the current and controversial issues in composition and TESOL (C\&T) studies: identity. Although identity at first glance may seem remotely related to the field of C\&T, when deeply considered, identity can be recognized as a core issue in C\&T studies because writing is one channel through which we 
express our identities, and in learning a second language we often renegotiate our identities. Ramsdell (2004) illustrated this point when he argued that "language is identity" (p. 166) and that the acquisition of a language is like the acquisition of selfhood. In this article, then, I look at how some C\&T scholars have investigated and framed the problem of identity.

Like their counterparts in other disciplines, C\&T scholars address issues that are problematic in their field such as identity and that-as argued by Maxwell (2005) - have ultimately personal, practical, or intellectual (scholarly) implications. In order to describe and analyze critically how the problem of identity has been addressed, I look at six articles and a book, starting from the problematic rise of identity in SLA research in 1997, which represented a paradigm shift, to other research dealing with second-language (L2) learner identity, identity in a teacher training program (i.e., identity of student teachers), and finally, teacher identity as transformative pedagogy. More specifically, I look at the following purposeful sample of C\&T studies: Block (2007), Yoshimoto (2008), Norton (2000), Ortmeier-Hooper (2008), Park (2008), and Morgan (2004).

In reviewing how these authors deal with the intricate issue of identity, I look for similarities and differences, trying to uncover consistent patterns in how they present the specific aspect(s) of identity that they problematize. That is, I look at how they persuade their readership that how they look at identity is worth considering, to what extent they actually address the phenomenon under investigation, and what arguments they use to back up their claims.

\section{Review}

First, Block's (2007) article on the rise of identity in SLA research is a seminal work in identity-related studies in the field. Block problematizes the relation between L2 learning and identity on a theoretical level. He does not conduct a study; he reviews earlier work, both theoretical and empirical, and then draws his own conclusion, which he persuades readers to endorse. To do so, he reviews the literature on certain theoretical studies on the one hand, and then discusses empirical research linking L2 learning and identity on the other. In building his case for the legitimate rise of identity in SLA research, Block presents a captivating discussion of the reconceptualization of SLA research that has been brought to light by Firth and Wagner (1997). Block argues that although Firth and Wagner do not deal explicitly with the issue of identity in SLA research, their article is in Kuhn's (1962) terms, a paradigm shift from cognitive and mentalistic orientations to more social and contextual orientations in SLA research. The earlier prevailing research paradigm had "a mindset that elevates an idealized 'native speaker' above a stereotypicalized 'nonnative,' while viewing the latter as a defective communicator, limited by an underdeveloped communicative competence" (Firth \& Wagner, p. 285). Thus according to Block, Firth and Wagner deal with "the narrow view of 
identity underlying most second language (L2) learning research" (p. 285), which other publications in the mid-1990's depict as "symptomatic of a general uneasiness about a certain conceptual and epistemological narrowness in the field" (pp. 863-865). Block reports on Firth and Wagner's work as the pivotal component of the scholarly discussion on identity, followed by Gass's (1998) response to them. Such dialogic discussions in any field can lead to major advancements, as did the explicit and open dialogue between Piaget and Vygotsky in relation to language and cognitive development as parallel ways to constructivism (Zender, 1973). Indeed, Gass's response to Firth and Wagner that "relevance [of identity] has to be established theoretically insofar as it affects the acquisition of a L2" (p. 86) received an extensive reply in the form of burgeoning publications on the relationship between identity and L2 learning, for example, Norton (2000), Pavlenko and Blackledge (2004), and Block (2006), to cite a few.

After situating the problem on an epistemological and theoretical level, Block (2007) moves on to discuss empirical studies that link identity and L2 learning in three contexts, namely, naturalistic, foreign language, and study abroad, as in his own (2006) work that addresses multilingual identities in cosmopolitan London; Pavlenko and Blackledge's (2004) work on the negotiation of identity by minority speakers in multilingual contexts where they have to learn and use English; and Norton's (2000) collection of case studies that look at how an L2 is learned, under what circumstances it is spoken, and how language teachers can address the delicate and diversified experiences of L2 learners. These are a few of the works that Block cites to demonstrate the paradigm shift in SLA research, which is a strategic argument that strengthens the case that Block (2007) makes for studying identity in L2 learning. In other words, he not only justifies the importance of studying L2 learning in relation to identity on an epistemological and theoretical level, but also reinforces it on an empirical level by giving a multidimensional view of L2 learning from three distinct perspectives that all validate the necessity to study and link identity with L2 learning in SLA research.

The second work that I briefly review is Yoshimoto's (2008) book. In this book-including a narrative piece, a collection of case studies, and an autoethnography-Yoshimoto also problematizes identity in relation to languagelearning. Her goal is to address the phenomenon of the identity change of English-language learners and to acknowledge by the same token that the aim of her study is both personal and practical. After situating her study in the literature by reviewing other works such as Norton's (2000) research on identity and language-learning in relation to investment rather than motivation, she also considers other studies that look at the language-learner and particular linguistic features such as syntax, lexis, and morphology. In this respect, there was clearly a void with respect to how second-language learners constructed identity and expressed feelings metaphorically. This was Yoshi- 
moto's entry point into the conversation on second-language learning and renegotiation of learner identity in relation to ideological and poetic metaphors developed in the discourse of the third space where the learner is no longer in the first-language realm, but has not yet fully reached the English space. It is in this respect that the identity-related problem that Yoshimoto addresses stands out in the literature on language and identity.

The third piece of research into identity and second-language learning is a chapter in Norton (2000) entitled "Eva and Mai: Old Heads on Young Shoulders." Before this chapter, Norton reviews earlier research in languagelearning on motivation, a notion that she finds too narrow in that it fails to account for how and under what conditions language-learners speak the L2. Although language-learners learn the L2 and attain varying degrees of proficiency, they fail to speak it in some sites. According to Norton, this has to do not with their motivation, but with their "investment" (p. 10). This is why in the chapter under review she addresses the problematic relationship between investment, identity, and language-learning in varied sites. Existing research deals with learner identity in the classroom context as if the negotiation of identity ceased beyond the classroom site. Norton's important contribution and advancement in the field of identity and L2 learning in this chapter is based on a case study of Eva and Mai, two L2 learners who construct their identities in two sites, namely, the workplace and the home, where their identities intersect. Norton seeks to answer the question of how female L2 learners construct their identities when they navigate through distinct contexts that put varying demands on them. The L2 learning experience of the first participant crystallizes her resistance to the patriarchal social structure in her home and her redefinition of herself in the workplace where she is both learning and using English, a language that empowers her. In a similar vein, Mai resists her brother's patriarchal authority. She has a complex linguistic tapestry at home, and she has to negotiate her identity in many languages at home as well as in English in the workplace. Norton's work in this chapter helps to answer the intricate question of the relationship between investment, identity, and language-learning in that investment helps identity to fuel learning, which in turn reshapes identity.

The fourth piece of research, by Ortmeier-Hooper (2008), links both the C\&T fields strategically. Her study addresses the question of how first-year ESL or 1.5-generation students negotiate their identities as L2 writers in mainstream composition classrooms. She uses both generation 1.5 and ESL interchangeably although they are actually different. Generation 1.5 students are immigrant students who have moved to an Anglophone setting like the United States, have enrolled in middle or high school (Rumbaut \& Ima, 1988), and who tend to have native-like oral competence. ESL learners are "international students who have learned English formally, are literate in their native language, and are accomplished students in their home countries; or ... 
students who have had limited exposure to English and to U.S. culture and education" (Harklau, 2003, para. 4).

Ortmeier-Hooper (2008) starts with a historical overview of the reasons that interested scholarly researchers in second-language writers at colleges and universities, namely, their increasing number and the ease of identifying them by institutional means such as governmental census and university admission records. After this, she discusses the problematic labels generation 1.5, ESL, and ELL for both students and composition teachers. She stimulates reflection on these labels and the potential problems associated with them. For example, as a teacher of English as a foreign language (EFL) and an English teacher educator, I myself had already been responding to her essay by critically reflecting on these labels and what they meant to me and to my students in my particular context, but more importantly to the targeted population in North America. To restate the problem that Ortmeier-Hooper identifies in an algorithmic way: first, in the US an increasing number of ESL, ELL, and 1.5 generation students are studying in colleges and universities. Second, the labels used to categorize or rather identify these students are problematic for teachers and students alike. Although such labels are descriptive, they can on the one hand have a tactical purpose for these students, who may expect teachers to be more lenient with them. Yet on the other hand, such labels can also have an emotional load because students may feel segregated and minoritized. Moreover, for teachers, these labels are institutional markers that require teachers in a composition class to deal with these students in a particular way. From this intricate and complicated configuration stems Ortmeier-Hooper's focus on how these students construct their identity in the composition class.

Because any student is part of a social group, Ortmeier-Hooper (2008) needed to define the social identity of students by reviewing the literature on social identity (Brooke, 1991), and then examine the theoretical stances linking identity to writing (Brooke; Ivanic, 1998; Newkirk, 1997). After doing this, she discusses how the above-mentioned labels are problematic to students who struggle with their sense of who they are at home and at school, and she examines new terms such as linguistic minority that have been proposed in other studies. In fact, these terms make the problem that she addresses even more sensitive and critical. Her detailed and thorough review of earlier empirical studies on immigrants in varied contexts sheds more light on the complexity of the problem she undertakes to tackle. Once OrtmeierHooper has presented her theoretical framework-which was Brooke's (1991) social identity model of how people identify themselves and how others in their environment identify them-she describes key aspects of the problem of immigrant students' identity formation in a writing class. The research method she uses is three case studies of students who have been given an opportunity to explore in a composition class how they negotiate their 
identities. To delve into ELL students' identity formation in writing, Ortmeier-Hooper triangulates data by using questionnaires, exploring samples of the students' writings, and following up with interviews. By using such a sound and sensitive data-collection procedure, she offers in her research a qualitative exploration of the problem at hand that invites more research to help solve the puzzle of student identity formation as voiced in their writings because her results inspire new ways to address this problem.

A fifth work is Park (2008), who problematizes:

how [she] was perceived and treated as a multi-competent ESL teacher as opposed to simply a non-native English-speaking teacher (NNEST) from a diverse linguistic, racial, and ethnic background, and how this identity coupled with the working environment influenced [her] pedagogical innovations within and beyond classroom contexts. (p. 18)

In fact, by framing the problem in this way, Park is bringing to the fore how she is perceived to counter and oppose the "normalizing gaze" (Foucault, 1995, p. 184) that is pervasive and normalized in a "normative discourse" (Foucault, 1980, p. 107) and that as such would objectify her individualism as a nonnative- English-speaking teacher along with the other aspects of her multidimensional identity such as race and ethnicity. Such categorizations would constrain and homogenize her and would consequently affect her agency, because by being objectified and reduced to such categories, Parklike any other NNEST - would be reduced as an individual, and the sum total of these categories could never equal who she really is as a teacher. However, thanks to her mentor and her supportive working environment, Park is able to enact pedagogical innovations in and beyond her classroom contexts. It is worth noting, however, that to enable the reader to conceptualize the real problem, which is one of power, Park proceeds methodologically. She starts her article by explicitly framing the issue, introducing the identity-related problems of a minority NNEST and the challenges she faces. She then extensively reviews the literature of earlier studies that looked at NNESTs in ESL/EFL contexts, focusing mainly on how those NNESTs were challenged and marginalized in their professions because of their non-native, non-White status, religion, race, or sex. She also highlights the fact that these publications have contributed to a better understanding of pre- and inservice teacher identity. However, despite this growing body of literature on NNEST- related issues, "there has been very little scholarly work documenting the teaching experiences of NNESTs working in community colleges, serving postsecondary, adult ESL students with varying educational and professional needs" (Park, 2008, p. 18). In other words, this is the gap in the literature that Park seeks to address, thus highlighting her contribution to the field of TESOL in general and to English teacher education in particular. Yet although I look 
only at how this purposeful sample of scholars deals with and problematized identity, I emphasize that Park's work stands out with respect to how she deals with the identity of an ESOL teacher through her experiences. She uses narrative to report her journey as a NNEST, then analyzes it reflectively by going inward and outward, backward but also forward (Clandinin \& Connelly, 2000), thus uncovering the main trends in the scholarly work done so far and concluding by "extending the dialogue" and inviting other NESTs and NNESTs to "become change agents in their own teaching journeys and the learning journeys of their students both within and beyond the classroom contexts" (Park, pp. 28-29) because this would ultimately help them to construct their identities and enact well-informed teaching practices.

I chose this last article as a sort of conclusion about how identity as a problem in C\&T has been framed in that it would specifically address teacher identity as pedagogy. Morgan (2004) problematized the role that teacher identity(ies) can play in countering students' stereotypes that are mere expressions of the normative discourse to which students have been subjected and which inhibits their agency or perpetuates their conformity to the dominant discourse. How Morgan articulates the problem is thought-provoking in that despite being highly conceptual, it offers a venue for language teachers to reflect on how their identities can be used to frame and inform their pedagogies in bilingual and ESL contexts. To achieve this, Morgan starts by reviewing how teacher identity has become a sub-field of bilingual and second-language education because of revolutionary ideas such as the native speaker fallacy (Phillipson, 1992) and World Englishes (Kachru, 1990), which were also reinforced by poststructural theories of discourse, subjectivity, and performaticity. According to Morgan, this explains how a teacher constructs an "image-text" of the self and "with each performance and the responses it engenders from students ... [becomes] aware of other ways to re-script [the self], that is, [the teacher] gain[s] insights into ways of subverting or transforming the 'rules' (e.g., educational practices) to which [the teacher has] been 'subjected'" (p. 173). However, the flip side of this issue is that by articulating their identity as transformative pedagogy, teachers might run the risk of exercising power over their students. This is why I believe that-as former language-learners, whether first, second, or foreign, former student teachers, or current teachers- "we need to present ourselves-our image-texts-in ways that are unthreatening and respectful, indeed, similar to other 'texts' we bring to class: always open to critical analysis and reinterpretation" (p. 184).

\section{Summation}

In this article, I look at identity as a recurrent theme in C\&T studies by attempting to trace in a purposeful sample the ontogenesis of identity, from the rise of identity in SLA research, to learners' identity, student-teachers' identity, and finally teachers' identity as transformative pedagogy. By so 
doing, I uncover some consistent patterns of problem identification that scholars use. Scholars may deal with a problem that has not yet been investigated: in other words, they may look at a gap in the literature and address it in order to contribute to their respective field such as is seen with Park's research. Other times, scholars may address a problem that is of a theoretical or practical nature such as the paradigm shift in SLA research that Block deals with, or Morgan's transformative pedagogy. However, no matter what the nature of the problem, scholars' challenge is to identify clearly the problem that they address and then clearly situate it in the field. They must review the literature of earlier studies that illuminate the problem-in this case, the issue of identity with its multidimensional, ongoing, changing, and adapting aspects-by focusing each time on individual cases or specific groups. Much attention is directed to who the individuals under study are, their sense of who they are in specific contexts, how they are perceived and constructed by other people, and why. Various directions can be taken to answer these questions by conducting empirical or theoretical studies. Researchers often make room for further research to remedy the shortcomings that they typically acknowledge in their own research or to open new paths that prospective researchers can take. By framing their problems in this way, researchers help to push understanding forward and at times generate new questions to answer because "the answer is to question" (Johnston, 2003, p. 1).

\section{The Author}

Hayat Messekher is a doctoral candidate in composition and TESOL at Indiana University of Pennsylvania. She has a master's degree in linguistics and English-language teaching from the University of Constantine, Algeria. She has also been an English teacher and teacher-educator at the Ecole Normale Supérieure des Lettres et Sciences Humaines de Bouzaréah, Algiers since 2003. Her research interests include teacher education, TEFL, TESOL, narrative inquiry, critical pedagogy, power and identity in language learning, and critical discourse analysis.

\section{References}

Block, D. (2006). Multilingual identities in a global city: London stories. London: Palgrave.

Block, D. (2007). The rise of identity in SLA research, post Firth and Wagner. Modern Language Journal, 91, 863-876.

Brooke, R.E. (1991). Writing and sense of self: Identity negotiation in writing workshops. Urbana, IL: NCTE.

Clandinin, D.J., \& Connelly, F.M. (2000). Narrative inquiry: Experience and story in qualitative research. San Francisco, CA: Jossey-Bass.

Firth, A., \& Wagner, J. (1997). On discourse, communication, and (some) fundamental concepts in SLA Research. Modern Language Journal, 81, 285-300.

Foucault, M. (1980). Two lectures. Power/knowledge: Selected interviews and other writings 19721977 (C. Gordon, Ed., pp. 78-108). New York: Pantheon Books.

Foucault, M. (1995). Discipline and punish: The birth of the prison (A. Sheridan, Trans.). New York: Vintage Books.

Gass, S. (1998). Apples and oranges: Or, why apples are not oranges and don't need to be. A response to Firth and Wagner. Modern Language Journal, 82, 83-90. 
Harklau, L. (2003). Generation 1.5 students and college writing. CAL Digests (EDO-FL-05-05). Retrieved 25 February, 2011, from: http://cal.org/resources/digest/0305harklau.html Ivani , R. (1998). Writing and identity: The discoursal construction of identity in academic writing. Philadelphia, PA: John Benjamins.

Johnston, K. (2003). The answer is to question. Paper presented at the Informing Science + Information Technology Education joint conference, Pori, Finland, June 22-27. Retrieved 25 February, 2011, from:

http:/ /informingscience.org/proceedings/IS2003Procedings/index.html

Kachru, B.B. (1990) The alchemy of English: The spread, functions, and models of non-native Englishes (2nd ed.). Urbana, IL: University of Illinois Press.

Kuhn, T.S. (1962). The structure of scientific revolutions. Chicago, IL: University of Chicago Press.

Maxwell, J.A. (2005). Qualitative research design: An interactive approach (2nd ed.). Thousand Oaks, CA: Sage.

Morgan, B. (2004). Teacher identity as pedagogy: Towards a field-internal conceptualization in bilingual and second language education. International Journal of Bilingual Education and Bilingualism, 7, 172-188.

Newkirk, T. (1997). The performance of self in student writing. Portsmouth, NH: Boynton/Cook.

Norton, B. (2000). Identity and language learning: Gender, ethnicity, and educational change. London: Longman.

Norton, B., \& Pavlenko, A. (Eds.). (2004). Gender and English language learners. Alexandria, VA: TESOL.

Ortmeier-Hooper, C. (2008). “English may be my second language, but I'm not 'ESL.'” College Composition and Communication, 59, 389-419.

Park, G. (2008). Lived pedagogies: Becoming a multicompetent ESOL teacher. In J.A. Carmona (Ed.), Perspectives on community college ESL, Volume 3: Faculty, administration, and the working environment (pp. 17-30). Alexandria, VA: TESOL.

Pavlenko, A., \& Blackledge, A. (Eds.). (2004). Negotiation of identities in multilingual contexts. Clevedon, UK: Multilingual Matters.

Phillipson, R. (1992). Linguistic imperialism. Oxford, UK: Oxford University Press.

Ramsdell, L. (2004). Language and identity politics: The linguistic autobiographies of Latinos in the United States. Journal of Modern Literature, 28, 166-176.

Rumbaut, R.G., \& Ima, K. (1988). The adaptation of Southeast Asian refugee youth. A comparative study. Final Report to the Office of Resettlement. San Diego, CA: San Diego State University. (ERIC Document Reproduction Service No. ED299372)

Yoshimoto, M. (2008). Second-language learning and identity: Cracking metaphors in ideological and poetic discourse in the third space. New York: Cambria Press.

Zender, B. (1973). A commentary on an unusual dialogue between Jean Piaget and Lev S. Vygotsky (ERIC Digest No. 082816). Retrieved March 12, 2011, from:

http://www.eric.ed.gov/PDFS/ED082816.pdf 